\title{
Contents: The Journal of the Sylvia Townsend Warner Society 21(1)
}

Editorial

ix

Peter Swaab

The Unfinished Sequel to The Corner That

Held Them (Part 2 of 2)

Sylvia Townsend Warner

'All across Europe it had come': The Black Death and Fascism in Sylvia Townsend Warner's The Corner That Held Them

Adam Piette

Hamlet in England

Sylvia Townsend Warner

Footsteps on the Battlements

Sylvia Townsend Warner

Stephen Tomlin in Chaldon Herring (1921-3)

Michael Bloch and Susan Fox

Sylvia Townsend Warner and Peter Pears: Loss and Friendship

Lynn Mutti

Book Review: lan Archie Beck, Through the Lens of Janet Stone: Portraits, 1953-1979

Judith Aronson

Book Review: Francesca Wade, Square Haunting:

Five women, freedom and London between the wars Hester Styles Vickery

This is an open-access article distributed under the terms of the Creative Commons Attribution Licence (CC-BY) 4.0 https://creativecommons.org/licenses/by/4.0/, which permits unrestricted use, distribution and reproduction in any medium, provided the original author and source are credited. https://doi.org/10.14324/111.444. stw.2021.00. (e-ISSN: 2398-0605). https://www.uclpress.co.uk/pages/the-journal-ofthe-sylvia-townsend-warner-society 